\title{
Evaluation of Tithonia-enriched Liquid Organic Fertilizer for Organic Carrot Production
}

\section{Fahrurrozi, Zainal Muktamar, Nanik Setyowati, Sigit Sudjatmiko, Mohammad Chozin}

Faculty of Agriculture, University of Bengkulu, Jalan WR Supratman, Bengkulu, 38125, Indonesia

Fahrurrozi, Z. M., Setyowati N., Sudjatmiko S. and Chozin M. (2015). Evaluation of Tithoniaenriched Liquid Organic Fertilizer for Organic Carrot Production. Journal of Agricultural Technology 11(8):1705-1712.

In organic vegetable production, foliar fertilizer is often applied in conjunction with soil amended fertilizer to provide sufficient nutrients for the plant growth and development. Liquid organic fertilizer (LOF) was locally produced using Tithonia diversifolia to improve organically grown of carrot (Daucus carota L.). This experiment aimed to determine the effectiveness of tithonia-enriched LOF on organic carrot production was arranged in completely randomized block design with three replicates. Treatments comprised five levels $(0,25,50,75$, and 100 ppm) of tithonia-enriched LOF concentrations, Results indicated that tithonia-enriched LOF did not significantly affect tuber length, tuber diameter, tuber fresh weight, shoot-tuber ratio, and number of tuber per plot. Future research should be focussed on the use of higher dosages of solid organic fertilizer and on application techniques of tithonia-enriched LOF.

Keywords: Tithonia diversifolia, Daucus carota L., liquid organic fertilizer, carrot yields

\section{Introduction}

Tithonia diversifolia (Hemsl.) A Gray, a shrub in the family Asteraceae and commonly known as Mexican sunflower, is widely distributed along feeder roads, waterways and farm boundaries as well as on cultivated farmlands in the humid tropics of Rejang Lebong highland, Bengkulu, Indonesia. Although tithonia is considered as annual and aggressive weed that harmful to many vegetable crops, this plant is widely used in traditional medicines, such as preventing diabetes (Firdous, 2014), malaria (Oyewole et al., 2008).

During the last decade, there has been growing interests to use tithonia's green biomass for organic vegetable production (Jama et al., 2000; Nziguheba et al., 2002; Olabode et al., 2007). The use of local materials, including green biomass, local waste from animals, and local microorganism is an essential part

Corresponding Author: Fahrurrozi, E-mail: fahrurrozi@unib.ac.id 
of organic vegetable production practices. The green biomass of tithonia has aroused research interests because of the relatively high nutrient concentrations found in its biomass and its ability to extract relatively high amounts of nutrients from soil (Forth and Ellis, 1997). Research conducted by Jama et al. (2000) revealed green leaf biomass of tithonia content averaging about $3.5 \% \mathrm{~N}$, $0.37 \% \mathrm{P}$ and $4.1 \% \mathrm{~K}$ on a dry matter basis. According to Olabode et al. (2007), chemical properties of organic matter, $\mathrm{N}, \mathrm{P}, \mathrm{K}, \mathrm{Ca}, \mathrm{Mg}, \mathrm{C}$ and $\mathrm{C} / \mathrm{N}$ in Tithonia diversifolia were $24.04 \%, 1.76 \%, 0.82 \%, 3.92 \%, 3.07 \%, 0.005 \%, 14.00 \%$ and 8:1, respectively. Furthermore, Olabode et al. (2007) and Pena et al. (2013) recommended the use of tithonia as a green manure or as a major component of compost manure for organic crop production. Sudjatmiko et al. (2013), Setyowati (2014) and Fahrurrozi et al. (2014) introduced the use of tithonia plants as a source of LOF for vegetable production in closed agriculture system in humid tropical highland of Bengkulu, Indonesia.

Solid organic fertilizer has been widely applied for nutrient supply in organic vegetable production. However, it is very often that solid organic fertilizer takes longer time to mineralize than crop life-cycle. According to Forth and Ellis (1997) after 90 days application of solid organic fertilizer, there were only about $50 \%$ of its $\mathrm{N}, \mathrm{P}$, and $\mathrm{K}$ get mineralized. Another report confirmed that most composts mineralized $<10 \%$ of initial $\mathrm{N}$ content in the 4 to 6 months after the application into the soil (Hartz et al., 2000). This slowrelease characteristic of solid organic fertilizer endorsed the application of liquid organic fertilizer (LOF) through leaves to fulfil nutrient required for vegetable growth and development. It is therefore recommended that combined soil and foliar applications should be conducted to increase both crop productivity and yield quality in organic vegetable production system, including carrots.

Carrot (Daucus carota L.) is an essential root vegetable for human health due its abundant source of carotene; a precursor of Vitamin A (Zeb and Mahmood, 2004) and other quantities of nutrients and minerals (Nicolle et al., 2004). According to Brandt et al. (2004) carrot consumption strengthens the immune system, protect against cancer, high blood pressure, osteoporosis, cataracts, atherosclerosis and heart diseases. Meanwhile, demands for organically grown carrot has steadily increased among the consumers. The use of tithonia-enriched LOF might be practiced to provide healthier and safer carrots for consumers. However, the effects of tithonia-enriched LOF in organic carrot production have not been evaluated in many growing areas. In addition to crop species, fertilizer form, frequency of application and the stage of plant growth, concentration of LOF applied to vegetable crops, is among the 
key factor to determine the successfulness of LOF application (Taura and Fatima, 2008).

This study is therefore aimed to determine the optimum concentration of tithonia-enriched LOF on growth and yield of organic carrot production.

\section{Materials and methods}

A field experiment was conducted on sandy loam of Inceptisol during dry season from July to October 2014 at Closed Agriculture Production System (CAPS) Research Station (950 m above sea level) located in Air Duku Village, Rejang Lebong, Bengkulu Province, Indonesia. This single factor experiment was arranged in completely randomized block design with three replicates. The treatments were $0,25,5075$ and 100 ppm of tithonia-enriched LOF.

Tithonia-enriched LOF was produced in CAPS Research Station by mixing $10 \mathrm{~kg}$ cattle's faeces, 201 cattle's urine, $5 \mathrm{~kg}$ of topsoil, $10 \mathrm{~kg}$ of Tithonia diversifolia (Hamsley) A. Gray), 201 solution of 24-hour incubated $20 \mathrm{ml} \mathrm{EM} 4+0.25 \mathrm{~kg}$ white sugar. All these materials were then mixed and added with water in the blue plastic container to reach a volume of 2001 and incubated for three weeks with daily mixing up to provide sufficient aerobic environment. After incubation, the mixture was sieved using white cloth and ready for application.

Experimental plots were located on the site that have continuously been cropped to organic vegetables since 2011 where organic fertilizer at rate of 15 ton $\mathrm{ha}^{-1}$ had been incorporated to soil in each season. No additional synthetic fertilizer had been applied to soil since 2011. A week before seeding, each soilbed was fertilized with $7.5 \mathrm{~kg}$ of vermicompost (equals to 15 ton $\mathrm{ha}^{-1}$ ).

Seeds of well-adapted carrot variety, Lilin Variety, were directly planted onto 3 blocks of soil beds that consisting of 15 plots $(1 \mathrm{~m}$ width, $5 \mathrm{~m}$ length and $0.3 \mathrm{~m}$ height) per block. Seedings were manually conducted on July $15^{\text {th }} 2014$ in crossing plot-lines which are $0.3 \mathrm{~m}$ in distances to form 16 seeding rows. Carrots were manually thinned in each seeding row on September $12^{\text {th }}$, 2014 to make plant spacing of $0.3 \mathrm{~m} \times 0.1 \mathrm{~m}$. The total number of carrot plants per plot was 144 plants. Carrots were also manually irrigated every other two day until the soil reached field capacity and stopped when precipitations took place. Manual weeding was conducted as necessary. At the time of weeding, soil around the stem was raised up to prevent tuber from sun exposure.

Each plot received 2000 (August $24^{\text {th }}, 2014$ ), 4000 (September $7^{\text {th }}$, 2014), 4000 (September $23^{\text {rd }}, 2014$ ), and 4000 (October $7^{\text {th }}$ ) $\mathrm{ml}$ of tithoniaenriched LOF with the concentration of $0,25,50,75$, and $100 \mathrm{ppm}$, respectively. Application was conducted during calm day and no rain using 
knapsack sprayer. Carrots were manually harvested at 101 days after planting (October $\left.21^{\text {st }}, 2014\right)$ and immediately washed with fresh-water. Effects of treatments were observed on tuber length, tuber diameter, tuber fresh weight, shoot-tuber ratio, and number of tuber per plot. Data were statistically analyzed by using PROC GLM in Statistical Analysis System version 9.1.3 portable at $\mathrm{P}$ $<0.05$.

\section{Results}

Results indicated that tithonia-enriched LOF did not significantly affect tuber length, tuber diameter, shoot fresh weight, tuber fresh weight, shoot-tuber ratio, number of tuber per plot, and tuber weight per plot of carrot (Table 1). Although did not influence all observed parameters, including tuber weight, Table 1 also implied that carrots sprayed with 0, 25, 50, 75 and $100 \mathrm{ppm}$ tithonia-enriched LOF produced carrot tubers as much as 11.89, 12.85, 13.15, 7.87 and 9.62 ton $\mathrm{ha}^{-1}$, respectively.

Table 1. Concentration effects of tithonia-enriched LOF on tuber length (TL), tuber diameter (TD), tuber fresh weight (TFW), shoot-tuber ratio (STR), and number of tuber per plot (NTp)

\begin{tabular}{|l|l|l|l|l|l|}
\hline Concentration & TL $(\mathrm{cm})$ & TD $(\mathrm{cm})$ & TFW $(\mathrm{g})$ & STR & NTp \\
\hline $0 \mathrm{ppm}$ & 16.83 & 2.62 & 96.69 & 0.32 & 82.00 \\
\hline $25 \mathrm{ppm}$ & 18.45 & 2.66 & 97.70 & 0.38 & 87.67 \\
\hline $50 \mathrm{ppm}$ & 18.29 & 2.50 & 99.25 & 0.33 & 88.33 \\
\hline $75 \mathrm{ppm}$ & 16.23 & 2.36 & 82.93 & 0.26 & 63.33 \\
\hline $100 \mathrm{ppm}$ & 15.25 & 1.94 & 81.19 & 0.27 & 79.00 \\
\hline Anova (Prob. > F) & 0.0016 & 0.0212 & 0.0937 & 0.4452 & 0.0012 \\
\hline Model & 0.0002 & 0.0071 & 0.0135 & 0.3606 & 0.0001 \\
\hline Block & 0.1229 & 0.1248 & 0.9018 & 0.4423 & 0.3373 \\
\hline Concentration & 8.74 & 13.19 & 33.06 & 27.24 & 18.99 \\
\hline CV (\%) & 0.7234 & 0.2898 & 0.5811 & 0.3377 & 0.1965 \\
\hline Orthogonal polynomial (Prob. > F) \\
\hline Linear & 0.0638 & 0.6247 & 0.6001 & 0.1880 & 0.1190 \\
\hline Quadratic
\end{tabular}

Our laboratory analysis revealed that this tithonia-enriched LOF contained 3,36 \% N, 146 ppm P, and $0.0325 \% \mathrm{~K}$. Nitrogen content of this LOF somehow comply to the standard quality for organic fertilizer issued by Indonesian Standardization Board (SNI 19-7030-2004) where total N should be $>0.4 \%$, but no the case of $\mathrm{P}$ and $\mathrm{K}$ which must be $>0.10 \%\left(\mathrm{P}_{2} \mathrm{O}_{5}\right)$ and $>$ $0.20 \%\left(\mathrm{~K}_{2} \mathrm{O}\right)$, respectively. 
This finding suggested that the use of tithonia-enriched LOF with these levels of concentration is not enough to promote carrot yields. Similar results on the use of tithonia-enriched LOF in humid area of Bengkulu were also previously reported on peanut (Kurniawan, 2015) and in sweet-corn (Joyosusino, 2015). Less responsive of carrot yield might be related to the fact that tithonia-enriched LOF used in this experiment had very low content of $\mathrm{P}$ (146 ppm) and $\mathrm{K}(0.0325 \%)$. This finding confirmed that the use of LOF Leachate in range of 20 to $60 \mathrm{ppm}$ did not increase growth and yield of carrot (Mardin and Dewanto, 2011). Although lack of P and K contained in tithoniaenriched LOF used in this experiment might have presumably limited tuber growth and development of carrot, such insignificance effects might be due to less effective of foliar applications for narrow-leaf vegetables, including carrot. This finding revealed tithonia-enriched LOF used in this experiment was not enough to complement the application of solid organic fertilizer applied to growing beds. Higher solid organic fertilizer should be employed for better yields of carrots. Sopha and Uhan (2013) suggested that the use of LOF should be combined with higher organic fertilizer ( $>15$ ton $\left.\mathrm{ha}^{-1}\right)$ since using higher concentration of LOF could delay nutrient uptake by plant.

There are several agronomical explanations, however, why tithoniaenriched LOF did not improve carrot's yields. The fact that carrot variety used in this experiment was a well-adapted variety to this growing area might be one of the explanations. This local variety might get enough nutrients from 15 ton $\mathrm{ha}^{-1}$ of vermicompost applied to experimental site, thus the additional foliar application might not been able to improve carrot yields. In the future, research might be focussed in the management of using LOF through foliar fertilizations, including dosages, time of application and technique of applications. According to Haytova (2013) the effectiveness of foliar fertilization is determined by the crop species, fertilizer form, concentration, frequency of application and the stage of plant growth. Inaddition, crop species and genetic factors are also determined the effectiveness of foliar fertilizations (Bueren et al., 2011).

Another reason might be related to the absence of surfactant during the application of LOF. It is generally understood that the use of surfactant was designed to improve liquid foliar fertilizing (Holloway and Stock, 1990) by improving LOF adhesion to the leaf surfaces, minimising the loss of LOF during the application and increasing LOF uptake into leaf cells. The effectiveness of surfactant in foliar fertilization improve crop yield has been previously reported muskmelon (Lester et al., 2006). The precense of leaf surfactant during LOF applications will increase its penetrations into leaf cells through leaf stomata and hydrophylic pores present on the leaf cuticules 
(Fernandez and Eichert, 2009). In addition, the structure of carrot leaves might not be suitable for LOF application. According to Hagin and Tucker (1982) foliar fertilization is more effective in broad leaves than narrow leaves. Pena et al. (2013) specifically concluded that tithonia-enriched organic fertilizer was effective to increase yield of leafy vegetables, such as pechay plant (Brassica rapa L.). Other reports also confirmed that the use of local LOF succesfully increased yields of broad-leaf vegetables such as lettuce (Surtinah, 2009; Damayanti et al., 2012), Chinese green cabbage (Nasution et al., 2014), cauliflower (Gomies et al., 2012), kaelan (Sinaga et al., 2014), potato (Parman, 2007) and tomato (Zhai et al., 2009).

In conclusion, this research demonstrated that tithonia-enriched LOF did not increase tuber length, tuber diameter, shoot fresh weight, tuber fresh weight, shoot-tuber ratio, and number of tuber per plot in organic carrot production. Future research should be focussed on the use of higher dosages of solid organic fertilizer in combination with present tithonia-enriched LOF. Research also should be focessed on application techniques of tithonia-enriched LOF for organic carrot production.

\section{Acknowledgement}

The authors would like to sincerely thank University of Bengkulu for financing this project through 2014 University Priority Research scheme. Acknowledgement is also extended to CAPS of Faculty of Agriculture, University of Bengkulu for providing lands and equipment for field experiments

\section{References}

Brandt, K., L.P. Christensen, J. Hansen-Mrller, S.L. Hansen, J. Haraldsdottir, L. Jespersen, S. Purup, A. Kharazmi, V. Barkholt, H. Frrkicr and M. Kobck-Larsen. 2004. Health Promoting Compounds in Vegetables and Fruits: A Systematic approach for Identifying Plant Components with Impact on Human Health. Trends in Food Sci. Technol. 15: 384-393.

Bueren. L.E.T., S.S. Jones, L. Tamm, K.M. Murphy, J.R. Myers, C. Leifert and M.M. Messmer. 2011. The need to breed crop varieties suitable for organic farming, using wheat, tomato and broccoli as examples : A review. Wageningen Journal of Life Sciences. 58:193-205.

Damayanti, N., N. Marlina, E. Hawayanti. 2012. Pengaruh Jenis Pupuk Organik Cair dan Takaran Pupuk Organik Plus terhadap Pertumbuhan dan Produksi Tanaman Selada (Lactuca sativa L.) pada Sistem Budidaya Vertikultur. Klorofil. 7:77-80. [In Indonesian Language].

Fahrurrozi, N. Setyowati, S. Sudjatmiko and M. Chozin. 2014. Establishment Sweet Corn Based Multiple Cropping in Closed Agricultural Production Systems at Air Duku 
Village, Rejang Lebong Highland: Challenges and Opportunities. Proc. 5th RENPER International Seminar, October 22-24, Banking Univ. Ho Chi Minh City, Vietnam

Fernadez, V. and T. Eichert. 2009. Uptake of Hydrophilic Solutes Through Plant Leaves: Current State of Knowledge and Perspectives of Foliar Fertilization. Critical Rev. in Plant Sciences 28:36-68.

Firdous, S.M. 2014. Phytochemicals for Treatment of Diabetes. EXCLI Journal13:451-453

Foth, H.D. and B.G. Ellis. 1997. Soil Fertility. $2^{\text {nd }}$ Ed. Lewis Publishers. Tokyo.

Gomies, L., H. Rehatta dan J. Nandissa. 2012. Pengaruh Pupuk Organik Cair RI1 terhadap Pertumbuhan dan Produksi Tanaman Kubis Bunga (Brassica oleracea L. Var. Botrytis). Agrologia. 1):13-20 [In Indonesian Language].

Hagin, J. and B. Tucker. 1982. Fertilization of Dryland and Irrigated Soil. Springs-verlag, Berlin. Helderberg Inc, Germany.

Hartz, T.K., J.P. Mitchell and C. Giannini. 2000. Nitrogen and Carbon Mineralization Dynamics of Manures and Composts. HortScience. 35:209-212.

Haytova, D. 2013. A Review of Roliar Fertilization of Some Vegetable Crops. Ann. Rev. and Res.in Biology. 4:455-465.

Holloway, P.J. and D. Stock. 1990. Factors Affecting the Activation of Foliar Uptake of Agrochemicals by Surfactants. In: D.S. Karsa (ed.), Industrial application of surfactants II. Royal Society of Chemistry. Special publication. 77. pp. 303-337.

Jama, B.C.A., R.J. Buresh, A. Niamg, C.N. Gachenco, G. Nziguheba and B. Amadalo. 2000. Tithonia diversifolia as Green Manure for Soil Fertility Improvement in Western Kenya. A Rev. Agroforest. Sys., 49: 201-221.

Joyosusino, A. 2015. Growth and Yield Responses on Organically Grown Sweet-corn to Various Concentration and Frequency of Liquid Organic Fertilizing. Undergraduate Fnal Project. Faculty of Agriculture. University of Bengkulu

Kurniawan, R. 2015. Growth and Yield Responses on Organically Grown Peanuts to Liquid Organic Fertilizing. Undergraduate Fnal Project. Faculty of Agriculture. University of Bengkulu

Lester, G.E., J.L. Jifon. and D.J. Makus. 2006. Supplemental Foliar Potassium Applications with or without a Surfactant can Enhance Netted Muskmelon Quality. HortScience. 41:741-744.

Mardin, S. and E. Dewanto. 2011. Kajian Pemanfaatan Pupuk Kandang Sapi dan Pupuk Organik Organik Cair Leachate terhadap Pertumbuhan dan Hasil Wortel (Daucus carota L.) di Dataran Rendah. Agronomika. 2:226-234. [in Indonesian Language]

Nasution, F. J., L. Mawarni and Meiriani. 2014. Aplikasi Pupuk Organik Padat dan Cair dari Kulit Pisang Kepok untuk Pertumbuhan dan Produksi Sawi (Brassica juncea L.). Online Agroekoteknologi. 1 :1029-1037. [In Indonesian Language]

Nicolle, C., Simon, G., Rock, E., Amouroux, P., and C. Remesy. 2004. Genetic Variability Influences on Carotenoids, Vitamin, Phenolic and Mineral Content in White, Yellow, Purple and Dark Orange Cultivars. Journal of Amer. Soc. Hort. Science, 129:523-529.

Nziguheba, G, R. Merckx, C.A. Palm and Mutuo. 2002. Combining Tithonia diversifolia and Fertilizers for Maize Production in a Phosphorus Deficient Soil in Kenya. Agroforestry Systems. 55:165-174

Olabode, O.S., Ogunyemi Sola, W.B. Akanbi, G.O. Adesina and P.A. Babajide. 2007. Evaluation of Tithonia diversifolia (Hemsl.) A Gray for Soil Improvement. World Journal of Agricultural Sciences 3:503-507.

Oyewole, I.O., C.A. Ibidapo, D.A. Moronkkola, A.O. Oduola, G.O. Adeoye, G.N. Anysor, and J.A. Obansa. 2008. Anti-malarial and Repellent Activities of Tithonia diversifolia (Hemsl.) Leaf Extracts. Journal of Medicinal Plants Research. 2:171-175. 
Parman, S. 2007. Pengaruh Pemberian Pupuk Organik Cair terhadap Pertumbuhan dan Produksi Kentang (Solanum tuberosum L.). Buletin Anatomi dan Fisiologi.15:21-31. [In Indonesian Language]

Pena, C.D., .D. L. I. Bartolome and T. P. Banwa. 2013. The Potential of Tithonia Diversifolia (Wild Sunflower) as Organic Foliar Fertilizer. European Scientific Journal. 4:465-468

Setyowati, N. 2014. Weed Sourced Organic Fertilizer for Vegetable Production in Closed Agriculture System in Humid Tropical Highland of Bengkulu. Proc. 5th RENPER International Seminar, October 22-24, Banking Univ. Ho Chi Minh City, Vietnam.

Sinaga, P., Meiriani and Y. Hasanah. 2014. Respons Pertumbuhan dan Produksi Kailan (Brassica oleraceae L.) pada Pemberian Berbagai Dosis Pupuk Organik Cair Paitan (Tithonia diversifolia Hemsl.) Gray). Online Agroekoteknologi. 2:584-1588. [In Indonesian Language]

Sopha, G.A. and T.S. Uhan. 2013. Application of Liquid Organic Fertilizer from City Waste on Reduce Urea Application on Chinese Mustrad (Brassica juncea L.) cultivation. $A A B$ Bioflux. 5:39-44. http://aab.bioflux.com.ro

Sudjatmiko, S., M. Chozin, Z. Muktamar and N. Setyowati. 2013. Closed Farming System : An Alternative Poverty Eradication in Kabupaten Rejang Lebong, Bengkulu Province, Indonesia. Proceeding $4^{\text {th }}$ International Seminar of Regional Network on Poverty Eradication.23-25 October 2013.

Surtinah. 2009. Pemberian Pupuk Organik Super Natural Nutrition (SNN) pada Tanaman Selada (Lactuca sativa L.) di Tanah Ultisol. Ilmiah Pertanian. 6:20-25. [In Indonesian Language]

Taura, D.W. and M.S. Fatima. 2008. Effects of Organic and Inorganic Fertilizers on the Vegetative and Reproductiove Parts of Some Selected Varieties of Cowpea. African Journal of General Agriculture. 4:79-86.

Zhai, Z., D.L. Ehret, T. Forge, W. Lin, M. Dorais, and P.A. Papadopoulos. 2009. Organic Fertilizers for Greenhouse Tomatoes: Productivity and Substrate Microbiology. HortScience. 44: 800-809.

Zeb, A., and S. Mahmood. 2004. Carotenoids Contents from Various Sources and Their Potential Health Applications. Pakistan Journal of Nutrition. 3:199-204. http://dx.doi.org/10.3923/pjn. 